\title{
Cystatin C Level in Prediabetic and Diabetic Patients
}

\author{
Şafak Akın, ${ }^{1}$ Banu Pınar Şarer Yürekli, ${ }^{2}$ Neşe Ersöz Gülçelik, \\ Jale Karakaya, ${ }^{3}$ Miyase Bayraktar, ${ }^{1}$ Aydan Usman'
}

\section{'Department of Endocrinology and Metabolism, Hacettepe University Faculty of Medicine, Ankara, Turkey \\ ${ }^{2}$ Department of Endocrinology and Metabolism, Ege University Faculty of Medicine, İzmir, Turkey \\ ${ }^{3}$ Department of Biostatistics, Hacettepe University Faculty of Medicine, Ankara, Turkey \\ Submitted: 15.02 .2017 Accepted: 07.03.2017 \\ Correspondence: Şafak Akın, Rize Eğitim ve Araştırma Hastanesi, Endokrinoloji Kliniği, Istanbul, Turkey \\ E-mail:safakcavus@gmail.com \\ Keywords: Cystatin C; diabetes mellitus; prediabetes.}

\begin{abstract}
Objective: Cystatin $C$ is a novel marker of kidney function. Serum Cystatin $C$ has been shown to correlate with the progression of prediabetes and type 2 diabetes mellitus. The aim of this study was to evaluate cystatin $C$ levels in diabetic and prediabetic patients and determine its association with anthropometric measurements and insulin resistance.
\end{abstract}

Methods: Twenty-five patients with diabetes, 17 patients with pre-diabetes and 24 healthy controls were included in the study. Baseline fasting plasma glucose, postprandial glucose, $\mathrm{HbAlc}$, fasting insulin, microalbuminuria, renal function tests, liver function tests, and lipid profile were estimated. Body mass index (BMI) was calculated.

Results: Diabetic patients had higher body mass index (BMI) than controls $(p=0.01)$. Serum cystatin $C$ levels were similar between the three groups ( $p>0.05$ ). Sex and/or smoking had no effect on cystatin levels. Higher cystatin $C$ levels were negatively associated with microalbuminuria. Cystatin $C$ levels were correlated with $\mathrm{BMI}$ and HOMA-IR in pre-diabetic patients ( $p=0.039$ and $p<0.05$, respectively) but not in diabetic patients or controls, when adjusted for age and gender.

Conclusion: Serum cystatin $C$ levels are associated with BMI and insulin resistance in prediabetic patients. These results suggest that higher BMI levels are associated with high cystatin $\mathrm{C}$ levels, which is predictive of future risk of diabetes mellitus.

\section{INTRODUCTION}

Type 2 diabetes is a disease which causes important morbidity, and mortality. Early intervention during prediabetic period may significantly delay or prevent development of type 2 diabetes. Adipose tissue is an important factor in the progression of prediabetes to diabetes. Epidemiologic studies have demonstrated an increase in cystatin $C$ levels in obesity. ${ }^{[l]}$ Cystatin $C$ which is a protease inhibitor is filtered through glomeruli, and reabsorbed by proximal tubuli, and degraded. Some studies have demonstrated superiority of plasma cystatin C over creatinine in the prediction of glomerular filtration rate. ${ }^{[2,3]}$ Recent studies have demonstrated that cystatin- $C$ is not only a sensitive biomarker for renal dysfunction, but it is also associated with insulin resistance, and obesity. Recently, cystatin-C has been shown to predict type 2 diabetes. ${ }^{[4]}$ Besides in "Western New York" health study, higher cystatin C level has been shown to be a predictive factor in the progression from normal fasting blood glucose to prediabetes. ${ }^{[5]}$

In this study we aimed to evaluate the association between cystatin-C levels with anthropometric measurements, and insulin resistance in prediabetic, and diabetic patients.

\section{MATERIAL AND METHODS}

Patients with type 2 diabetes $(n=25)$, prediabetes $(n=17)$, and 24 healthy controls were included in the study. The study protocol was approved by the Ethics Committee of Hacettepe University School of Medicine. Impaired glucose tolerance was accepted as prediabetes. Baseline fasting plasma glucose (FPG), postprandial glucose (PPG), HbAlc, 
fasting insulin, microalbuminuria, renal function tests, liver function tests, and lipid profile were estimated.. Waist circumference, body weight, and height were measured according to standard protocol. Body mass index (BMI) was calculated by dividing body weight $(\mathrm{kg})$ by square of height $\left(\mathrm{kg} / \mathrm{m}^{2}\right)$. "Homeostasis Model of Assesment-Insulin Resistance" (HOMA-IR) were calculated based on the formula [fasting plasma glucose (mmol/L) $x$ fasting insulin (mmol/L)/22.5]. Serum cystatin $C$ was measured with ELISA test, and using commercially available kit (Biovdor, Czech Republic).

Data were analyzed using SPSS 16.0 software for Windows. Data were presented as mean \pm SD (standard deviation). For the comparison of variables among three groups, One Way Anova (Post Hoc Bonferroni correction) was used for variables with normal distribution, and for those asymmetrical distribution Kruskal-Wallis test was employed. For the comparison of categorical variables $\mathrm{Pe}$ arson chi-square test was used. $P<0.005$ was accepted as the level of statistical significance.

\section{RESULTS}

Study population consisted of 25 (M/F: 7//8) diabetic, 17
(M/F: 6/II), prediabetic patients, and 24 (M/F: 2/22) control subjects. Basic demographic, and laboratory values of the participants were presented in Table I. Serum cystatin $\mathrm{C}$ levels in control, prediabetic, and diabetic groups were $0.93 \pm 0.13,0.89 \pm 0.16$, and $0.96 \pm 0.16 \mathrm{mg} / \mathrm{L}$, respectively $(p=0.3 \mathrm{I})$. Cystatin $C$ levels were comparable between female, and male participants. BMI, waist, and hip circumference, and HOMA-IR values were higher in the diabetic group when compared with the control group $(p<0.05)$. Smoking status did not differ between groups $(p=0.49)$. Any intergroup difference was not detected as for systolic, and diastolic blood pressure measurements $(p=0.33$, and $\mathrm{P}=0.5 \mathrm{I}$, respectively). A significant intergroup difference did not exist as for creatinine levels $(p=0.25)$. When adjusted for age, and gender, cystatin $C$ levels in prediabetic patients correlated with BMI, and HOMA-IR $(p=0.039$, and $\mathrm{P}<0.05$, respectively).

\section{DISCUSSION}

This study has demonstrated the presence of a significant correlation between cystatin C levels, BMI, and HOMA-IR values in the prediabetic group. Reutens et al. have revealed that cystatin $C$ is an independent predictor of diabe-

Table I. Demographic and laboratory data of the participants

\begin{tabular}{|c|c|c|c|c|c|c|c|c|c|c|}
\hline & \multicolumn{9}{|c|}{ Groups } & \multirow[t]{3}{*}{$\mathbf{p}$} \\
\hline & \multicolumn{3}{|c|}{ Control $(n=24)$} & \multicolumn{3}{|c|}{ IGT $(n=\mid 7)$} & \multicolumn{3}{|c|}{ DM $(n=25)$} & \\
\hline & Mean $\pm S D$ & Min. & Max. & Mean $\pm S D$ & Min. & Max. & Mean $\pm S D$ & Min. & Max. & \\
\hline Age (year) & $44.13 \pm 13.1$ & 16 & 66 & $48.06 \pm 9.07$ & 29 & 64 & $53.52 \pm 8.18$ & 38 & 67 & 0.025 \\
\hline BMI $\left(\mathrm{kg} / \mathrm{m}^{2}\right)$ & $27.33 \pm 4.23$ & 20 & 37 & $29.73 \pm 4.65$ & 21 & 37 & $32.74 \pm 5.45$ & 23 & 46 & 0.002 \\
\hline Waist circumference $(\mathrm{cm})$ & $89.36 \pm 14.72$ & 70 & 119 & $96.69 \pm 11.48$ & 75 & 109 & $103.28 \pm 7.99$ & 86 & 124 & 0.002 \\
\hline $\mathrm{SBP}(\mathrm{mmHg})$ & $|2| .25 \pm 1 \mid .72$ & 99 & 156 & $124 \pm 13.67$ & 103 & $|5|$ & $|25.24 \pm 7.7|$ & 110 & 140 & 0.336 \\
\hline $\mathrm{DBP}(\mathrm{mmHg})$ & $79.5 \pm 8.5$ & 56 & 106 & $79.47 \pm 6.96$ & 60 & 90 & $81.2 \pm 6.17$ & 70 & 90 & 0.519 \\
\hline FPG (mg/dL) & $89.38 \pm 6.47$ & 79 & 100 & $104.71 \pm 12.02$ & 77 & 124 & $|4| .76 \pm 44.36$ & 90 & 260 & $<0.0001$ \\
\hline PPG (mg/dL) & $98.16 \pm 14.47$ & 68 & 125 & $\mid 40.24 \pm 29.93$ & 94 & 197 & $157.28 \pm 60.99$ & 89 & 336 & $<0.0001$ \\
\hline Insulin $(\mu \mathrm{U} / \mathrm{mL})$ & $10.95 \pm 3.81$ & 0.72 & 18 & $14.98 \pm 10.32$ & 5.5 & 49 & $17.69 \pm 12.18$ & 3.5 & 50 & 0.160 \\
\hline Homa-IR & $2.4 I \pm 0.86$ & 0.16 & 4.12 & $3.76 \pm 2.5$ & $\mathrm{I} .54$ & 11.25 & $6.8 \pm 6.78$ & 1.81 & 30.81 & 0.002 \\
\hline T. Chol. (mg/dL) & $194.05 \pm 31.25$ & 142 & 275 & $194.94 \pm 24.27$ & 147 & 227 & $167.96 \pm 47.22$ & 13 & 242 & 0.051 \\
\hline TG (mg/dL) & $127.36 \pm 77.64$ & 44 & 363 & $139.69 \pm 52.92$ & 74 & 223 & $169.08 \pm 95.18$ & 51 & 436 & 0.179 \\
\hline $\mathrm{HDL}(\mathrm{mg} / \mathrm{dL})$ & $56.39 \pm 14.06$ & 32 & 88 & $48.29 \pm 7.37$ & 34 & 67 & $45.94 \pm 12.1$ & 23 & 76 & 0.018 \\
\hline LDL (mg/dL) & $112.82 \pm 22.4$ & 73 & 164 & $125.5 \pm 25.35$ & 81 & 160 & $99.76 \pm 27.63$ & 54 & 162 & 0.017 \\
\hline BUN (mg/dL) & $12.42 \pm 3.15$ & 7 & 20 & $13.94 \pm 3.21$ & 6 & 18 & $14.39 \pm 2.9$ & 9 & 19 & 0.047 \\
\hline Creatinine (mg/dL) & $0.7 I \pm 0.13$ & 0.5 & 0.99 & $0.7 \pm 0.15$ & 0.5 & 0.95 & $0.76 \pm 0.14$ & 0.39 & 0.99 & 0.250 \\
\hline CystatinC (mg/L) & $0.93 \pm 0.13$ & 0.7 & 1.2 & $0.89 \pm 0.16$ & 0.6 & 1.2 & $0.96 \pm 0.16$ & 0.7 & 1.3 & 0.311 \\
\hline
\end{tabular}


tes in patients with larger waist circumference, increased fat mass, and insulin resistance. ${ }^{[6]}$ In this cohort study, use of cystatin $C$ could predict risk of diabetes better in the group with only central adiposity, and insulin resistance. However this correlation did not exist in patients with decreased fat mass. In the Framingham Offspring study a correlation between cystatin C levels, and BMI was found. [7] Cystatin $C$ is released in higher concentration in omentum, and subcutaneous fat tissue ${ }^{[1]}$ When compared with non-obese individuals two or three times higher amounts of cystatin $C$ secretion were demonstrated from adipose tissue explants. ${ }^{[1]}$ This finding suggest the presence of a probable interplay between cystatin $\mathrm{C}$, and cathepsins playing a role in adipogenesis. ${ }^{\left[{ }^{8]}\right.}$ In obesity many biocative molecules released from adipose tissue may be responsible from the development of cardiovascular disease, and disordered homeostasis of glucose. Cathepsin family (cathepsin K, L, and S) are newly discovered potential molecules. Inhibition of cathepsins may decrease cardiovascular risk. Increased serum cystatin $C$ in obesity may have a protective role through inhibition of cathepsin production. ${ }^{[8]}$

Some studies cited in the literature have indicated that cystatin $\mathrm{C}$ might be a predictor of metabolic syndrome. [9-1I] Apart from obesity, inflammation, and oxidative stress may be other etiologic factors which induce increases in cystatin-C levels. Induction of cystatin C mRNA, and protein synthesis by oxidative stress has been demonstrated in many studies. ${ }^{[1]}$

The relationship between renal dysfunction defined with decreased glomerular filtration rate (GFR), and development of diabetes has been demonstrated. ${ }^{[12]}$ This condition might be related to insulin resistance, ${ }^{[13]}$ increased renal glukoneogenesis, ${ }^{[14]}$ endothelial dysfunction and/or chronic inflammation, oxidative stress ${ }^{[14,15]}$ and activation of the renin- angiyotensin system. ${ }^{[16]}$ In the prediction of the presence of early renal dysfunction serum cystatin $C$ has been thought to be more definitive parameter than serum creatinine. ${ }^{[17-19]}$ In recent investigations, the correlation between cystatin $\mathrm{C}$, and obesity, hypertension, and insulin resistance which is closely related to diabetes has been suggested. ${ }^{[10]}$ In our study cystatin $C$ levels were comparable in diabetic, prediabetic, and control groups, and we have also demonstrated a positive correlation between cystatin $\mathrm{C}$ levels, $\mathrm{BMI}$, and insulin resistance in the prediabetic group.

Scarce number of patients in groups constitute a limitation of this study. This cross-sectional study does not indicate the presence of cause-effect relationship. Therefore prospective studies are needed to clarify this issue.

A complex relationship exists between adiposity, cystatin $\mathrm{C}$, and glycemic homeostasis. It is not absolutely certain whether cystatin $C$ can be a predictive biomarker for impaired glucose tolerance, and developing diabetes. Further studies which will clarify, and evaluate this complex issue are needed.

Authorship contributions

Concept: Ş.A.; Design: Ş.A., B.P.Ş.Y; Data collection \&/or processing: Ş.A; Analysis and/or interpretation: Ş.A., J.K., N.E.G.; Writing: Ş.A.; Critical review: Ş.A., N.E.G., M.B., A.U.

Conflict of interest

None declared.

\section{REFERENCES}

1. Naour N, Fellahi S, Renucci JF, Poitou C, Rouault C, Basdevant A, et al. Potential contribution of adipose tissue to elevated serum cystatin $C$ in human obesity. Obesity (Silver Spring) 2009;17:2121-6. [CrossRef]

2. Dharnidharka VR, Kwon C, Stevens G. Serum cystatin C is superior to serum creatinine as a marker of kidney function: a meta-analysis. Am J Kidney Dis 2002;40:221-6. [CrossRef]

3. Roos JF, Doust J, Tett SE, Kirkpatrick CM. Diagnostic accuracy of cystatin $\mathrm{C}$ compared to serum creatinine for the estimation of renal dysfunction in adults and children-a meta-analysis. Clin Biochem 2007;40:383-91. [CrossRef]

4. Sahakyan K, Lee KE, Shankar A, Klein R. Serum cystatin C and the incidence of type 2 diabetes mellitus. Diabetologia 2011;54:133540. [CrossRef]

5. Donahue RP, Stranges S, Rejman K, Rafalson LB, Dmochowski J, Trevisan M. Elevated cystatin C concentration and progression to pre-diabetes: the Western New York study. Diabetes Care 2007;30:1724-9. [CrossRef]

6. Reutens AT, Bonnet F, Lantieri O, Roussel R, Balkau B; Epidemiological Study on the Insulin Resistance Syndrome Study Group. The association between cystatin $\mathrm{C}$ and incident type 2 diabetes is related to central adiposity. Nephrol Dial Transplant 2013;28:1820-9. [CrossRef]

7. Parikh NI, Hwang SJ, Yang Q, Larson MG, Guo CY, Robins SJ, et al. Clinical correlates and heritability of cystatin C (from the Framingham Offspring Study). Am J Cardiol 2008;102:1194-8. [CrossRef]

8. Lafarge JC, Naour N, Clément K, Guerre-Millo M. Cathepsins and cystatin $\mathrm{C}$ in atherosclerosis and obesity. Biochimie 2010;92:1580-6.

9. Retnakaran R, Connelly PW, Harris SB, Zinman B, Hanley AJ. Cystatin $\mathrm{C}$ is associated with cardiovascular risk factors and metabolic syndrome in Aboriginal youth. Pediatr Nephrol 2007;22:1007-13.

10. Servais A, Giral P, Bernard M, Bruckert E, Deray G, Isnard Bagnis C. Is serum cystatin- $\mathrm{C}$ a reliable marker for metabolic syndrome? Am J Med 2008;121:426-32. [CrossRef]

11. Demircan N, Gurel A, Armutcu F, Unalacak M, Aktunc E, Atmaca $\mathrm{H}$. The evaluation of serum cystatin $\mathrm{C}$, malondialdehyde, and total antioxidant status in patients with metabolic syndrome. Med Sci Monit 2008;14:CR97-101.

12. Lorenzo C, Nath SD, Hanley AJ, Abboud HE, Gelfond JA, Haffner SM. Risk of type 2 diabetes among individuals with high and low glomerular filtration rates. Diabetologia 2009;52:1290-7. [CrossRef]

13. Fox CS, Larson MG, Leip EP, Culleton B, Wilson PW, Levy D. Predictors of new-onset kidney disease in a community-based population. JAMA 2004;291:844-50. [CrossRef]

14. Meigs JB, Hu FB, Rifai N, Manson JE. Biomarkers of endothelial dys- 
function and risk of type 2 diabetes mellitus. JAMA 2004;291:197886. [CrossRef]

15. Ramos LF, Shintani A, Ikizler TA, Himmelfarb J. Oxidative stress and inflammation are associated with adiposity in moderate to severe CKD. J Am Soc Nephrol 2008;19:593-9. [CrossRef]

16. Tikellis C, Wookey PJ, Candido R, Andrikopoulos S, Thomas MC, Cooper ME. Improved islet morphology after blockade of the reninangiotensin system in the ZDF rat. Diabetes 2004;53:989-97.

17. Coll E, Botey A, Alvarez L, Poch E, Quintó L, Saurina A, et al. Serum cystatin $\mathrm{C}$ as a new marker for noninvasive estimation of glomerular filtration rate and as a marker for early renal impairment. Am J Kidney Dis 2000;36:29-34. [CrossRef]

18. Newman DJ, Thakkar H, Edwards RG, Wilkie M, White T, Grubb $\mathrm{AO}$, et al. Serum cystatin $\mathrm{C}$ measured by automated immunoassay: a more sensitive marker of changes in GFR than serum creatinine. Kidney Int 1995;47:312-8. [CrossRef]

19. Willems D, Wolff F, Mekahli F, Gillet C. Cystatin C for early detection of renal impairment in diabetes. Clin Biochem 2009;42:108-10.

\section{Diyabetik ve Prediyabetik Bireylerde Sistatin C Düzeyi}

Amaç: Sistatin $C$ böbrek fonksiyonunun yeni bir belirtecidir. Serum sistatin C'nin prediyabet ve tip 2 diabetes mellitus progresyonuyla korele olduğu gösterilmiştir. Bu çalışmanın amacı, diyabetik ve prediyabetik hastalarda sistatin C düzeylerini değerlendirmek ve antropometrik ölçümler ile insülin direnci arasındaki ilişkiyi saptamaktır.

Gereç ve Yöntem: Diyabetik 25 hasta, prediyabetik 17 hasta ve 24 sağılıklı kontrol çalışmaya alındı. Başlangıç açlık plazma glukozu, post prandial glukoz, HbAlc, açlık insülin, mikroalbuminüri, böbrek fonksiyon testleri, karaciğer fonksiyon testleri ve lipid profili ölçüldü. Bel çevresi, vücut ağılığı ve boy standart protokole göre ölçüldü. Vücüt kitle indeksi (VKi) hesaplandı.

Bulgular: Diyabetik hastalarda kontrol grubuna göre VKi daha yüksekti $(p=0.01)$. Serum sistatin $C$ düzeyleri üç grup arasında benzerdi $(p>0.05)$. Cinsiyet ve/veya sigara içilmesinin sistatin seviyeleri üzerinde herhangi bir etkisi görülmedi. Yüksek sistatin $C$ düzeyleri mikroalbüminüri ile negatif ilişkili idi. Yaş ve cinsiyete göre ayarlama yapıldığında prediyabetik hastalarda sistatin C düzeyleri, VKi ve HOMA-IR ile korelasyon gösterdi (sırasıyla, $\mathrm{p}=0.039$ ve $\mathrm{p}<0.05$ ).

Sonuç: Prediyabetik hastalarda serum sistatin C düzeyleri VKi ve insülin direnci ile ilişkilidir. Bu sonuçlar, daha yüksek VKi düzeylerinin gelecekte diyabet riskini öngören yüksek sistatin $C$ seviyeleri ile ilişkili olduğunu düşündürmektedir.

Anahtar Sözcükler: Diyabet; prediyabet; sistatin C. 